\title{
Triple Bottom Line and Sustainability: A Literature Review
}

\author{
Hanan Alhaddi \\ Correspondence: Hanan Alhaddi, College of Management, Lawrence Technological University, MI, USA
}

\author{
Received: February 2, 2015 Accepted: February 15, 2015 Online Published: April 3, 2015 \\ doi:10.11114/bms.v1i2.752 \\ URL: http://dx.doi.org/10.11114/bms.v1i2.752
}

\begin{abstract}
Triple bottom line (TBL) and sustainability are two related constructs that are used interchangeably in the literature. A comprehensive review of the relevant literature was conducted and revealed an inconsistent use of the term sustainability. On the other hand, consistency in terms of referring to the three lines simultaneously is built into the structure of TBL as the construct is explicitly based on the integration of the social, environmental, and economic lines. The purpose of this paper is not to support an argument that favors the use of one term over the other, but to provide an overview of the presence of both terms in the literature. In light of that, researchers in the business, management, and sustainability fields are encouraged to pay particular attention to how they use these terms in their studies.
\end{abstract}

Keywords: triple bottom line (TBL), sustainability, literature review comma

\section{Introduction}

Triple bottom line (TBL) is a sustainability-related construct that was coined by Elkington (1997). The origin of sustainability may date back to over 130 years ago from an idea known as spaceship earth (George, 1879/2009). Evolving over the years, the construct gained significant popularity with the emergence of the term "sustainable development" from the Brundtland Report in 1987. The report defined the term as the "development that meets the needs of the present generations without compromising the ability of the future generations to meet their own needs" (Brundtland, 1987, p 43). Driven by sustainability, TBL provides a framework for measuring the performance of the business and the success of the organization using three lines: economic, social, and environmental (Goel, 2010). In essence, TBL expresses the expansion of the environmental agenda in a way that integrates the economic and social lines (Elkington, 1997). In his definition of TBL, Elkington used the terms profit, people, and the planet as the three lines. In this study, the economic, social, and environmental lines referred to profit, people, and planet respectively.

Consistency in terms of referring to the three lines simultaneously is built into the structure of TBL as the construct is explicitly based on the integration of the social, environmental, and economic lines. Different than TBL, literature reviewed showed inconsistent usage of the sustainability term. For example, some studies used sustainability to primarily refer to the environmental line (Yan, Chen, \& Chang, 2009). Others used the term to refer to the social line (Bibri, 2008), while some used the term to refer to all three (Marcus \& Fremeth, 2009). In regards to balance, TBL places an equal level of importance on each of the three lines; this brings more balance and coherence into the construct (Elkington, 1997; Epstein, 2008; Harmon, Bucy, Nickbarg, Rao, \& Wirtenberg, 2009; Russell, Abdul-Ali, Friend, \& Lipsky, 2009; Savitz \& Weber, 2006). Other sustainability-related studies showed an imbalance in the level of importance distributed among the three lines. For example, although many studies included the economic line when referring to sustainability, the notion of its importance was limited (Collins, Steg, \& Konan, 2007).

\section{Literature Review Method}

The literature review presented in this paper was part of a larger review conducted by Alhaddi (2013). The consensus in the research is that TBL is a sustainability-related construct. Research has also shown that TBL is a consistent construct in terms of always referencing the economic, social, and environmental lines (Elkington, 1997). Consistency is built into the structure of TBL as the construct is explicitly based on the integration of the three lines. Additionally, TBL places an equal amount of emphasis on each of the three lines, which brings more balance and coherence into the construct (Elkington, 1997; Epstein, 2008; Harmon, Bucy, Nickbarg, Rao, \& Wirtenberg, 2009; Russell, Abdul-Ali, Friend, \& Lipsky, 2009; Savitz \& Weber, 2006). On the other hand, the literature reviewed showed a large number of sustainability studies where the study topic was sustainability, yet the ultimate focus was on either the environment or society. Therefore, a thorough review of the relevant literature was conducted to understand how each concept appeared in research. The purpose of the literature review was not to support an argument of TBL versus sustainability, but to 
shed light on how they appear in literature. This paper presents an overview of sustainability, followed by TBL, then concluded with few recommendations for researchers in the business, management, and sustainability fields.

\section{Sustainability}

Similar to the definition of sustainable development in the Brundtland report, Hart and Milsten (2003) defined sustainability as the expectations of improving the social and environmental performance of the present generation without comprising the ability of future generations to meet their social and environmental needs. Herman Daly's measurement-based definition of the term brought more environmental precision to the construct:

A sustainable society needs to meet three conditions: its rates of use of renewable resources should not exceed their rates of regeneration; its rates of use of non-renewable resources should not exceed the rate at which sustainable renewable substitutes are developed; and its rates of pollution of emission should not exceed the assimilative capacity of the environment. (Elkington, 1997, p. 55)

Despite the evolution of the sustainability construct, the essence of the idea remained the same; it was still an issue of needs weighed against limitations. Continuing to emerge from the spaceship earth idea and others like sustainable society (Santos \& Filho, 2005), the authors pointed out the consensus of these ideas with respect to society and the need for it to be in balance with its surroundings. Further, sustainability was referred to as a fundamental and complex construct that mandates the balance of several factors in order for the planet to continually exist (Aras \& Crowther, 2009). Yet, in its simplest form, sustainability refers to a value and a belief of the enhancement and preservation of the natural environment (Shrivastava \& Hart, 1992). Originated decades ago and through the significant momentum gained with the Brundtland Report (1987), the construct continued to gain attention becoming one of the most leading issues facing the world due to continuous pressure from the society and the stakeholders (Ambec \& Lanoie, 2008; Epstein, 2008; Lippman, 2010). Several definitions of sustainability were found in the literature; although they differed slightly based on the source, the core (with respect to the society and the environment) remained the same. For example, according to Dyllick and Hockerts (2002), sustainability represents the societal development and evolution in the direction of a wealthy and more comfortable world where the natural environment and cultural accomplishments are reserved for future generations. In addition to benefiting future generations, sustainability delivers value and financial gains in the present.

\subsection{Sustainability in the Literature}

The lack of a rigid framework for sustainability, presented a unique challenge in the literature: the use of the term sustainability seemed not to be consistent. Some sustainability studies discussed one line only (Bibri, 2008; Blengini \& Shields, 2010; Iles, 2008; McDonald \& Oates, 2006; Yan, Chen, \& Chang, 2008). Other studies combined two or more lines (Collins, Steg, \& Koning, 2007; Dewangga, Goldsmith, \& Pegram, 2008; Frame \& Newton, 2007; Kirchgeorg \& Winn, 2006). Only a handful of studies referred included the economic line whether independently or in conjunction with the other two lines (Collins, Steg, \& Koning, 2007; Kirchgeorg \& Winn, 2006). A sample of the results of the literature review were compiled and tabulated as shown in Table 1 below.

Table 1. Summary of Sustainability Studies

\begin{tabular}{lll}
\hline Sustainability study topic & Line & Author(s), year \\
\hline $\begin{array}{l}\text { Innovation in sustainability marketing } \\
\text { Towards sustainability }\end{array}$ & Environmental/green & Iles, 2008 \\
Sustainable corporate performance & Environmental & Peattie, 2001 \\
& Environmental & Collins, Steg, \& \\
& Social & Koning, 2007 \\
Economic & Blengini \& Shields, \\
Sustainability reporting & Environmental & 2010 \\
Promoting sustainability & Social & Frame \& Newton, \\
Sustainability and consumer perceptions & Environmental & 2007 \\
Sustainability and product constructualization & Environmental & McDonald \& Oates, \\
Sustainability and marketing & & 2006 \\
& Economic & Yan, Chen, \& Chang, \\
Corporate sustainability and marketing & Social & Kirchgeorg \& Winn, \\
Sustainable society & Social CSR & 2006 \\
& Environmental & Bibri, 2008 \\
\hline
\end{tabular}




\section{Triple Bottom Line (TBL)}

Referred to as "a brilliant and far-reaching metaphor" (Henriques, 2007, p. 26), the TBL construct was coined by Elkington (1997). Prior to the late 1990s, the term was not significantly known. Today, a basic Google search returns over three million web pages with the notion TBL, up from 52,400 web pages in 2004 (Norman \& MacDonal, 2004). In essence, TBL is another construct that expresses the expansion of the environmental agenda in a way that integrates the economic and social lines (Elkington, 1997). TBL provides a framework for measuring the performance of the business and the success of the organization using the economic, social, and environmental lines (Goel, 2010). The term has also been referred to as the practical framework of sustainability (Rogers \& Hudson, 2011). Targeted toward corporations, the TBL agenda puts a consistent and balanced focus on the economic, social, and environmental value provided by the organizations.

\subsection{Economic Line}

The economic line of TBL framework refers to the impact of the organization's business practices on the economic system (Elkington, 1997). It pertains to the capability of the economy as one of the subsystems of sustainability to survive and evolve into the future in order to support future generations (Spangenberg, 2005). The economic line ties the growth of the organization to the growth of the economy and how well it contributes to support it. In other words, it focuses on the economic value provided by the organization to the surrounding system in a way that prospers it and promotes for its capability to support future generations.

\subsection{Social Line}

The social line of TBL refers to conducting beneficial and fair business practices to the labor, human capital, and to the community (Elkington, 1997). The idea is that these practices provide value to the society and "give back" to the community. Examples of these practices may include fair wages and providing health care coverage. Aside from the moral aspect of being "good" to the society, disregarding social responsibility can affect the performance and sustainability of the business. Recent examples in the industries have revealed that there are economic costs associated with ignoring social responsibility. For instance, during the 2002 civic elections in the Bay area of California, the public voted against the establishment of a Home Depot due to their perception of its negative residential impact as a neighbor (Dhiman, 2008). The social performance focuses on the interaction between the community and the organization and addresses issues related to community involvement, employee relations, and fair wages (Goel, 2010).

\subsection{Environmental Line}

The environmental line of TBL refers to engaging in practices that do not compromise the environmental resources for future generations. It pertains to the efficient use of energy recourses, reducing greenhouse gas emissions, and minimizing the ecological footprint, etc. (Goel, 2010). Similar to the social aspect of TBL, environmental initiatives impact the business sustainability of the organizations. An analysis by Kearney (2009) was done on 99 sustainability-focused organizations across 18 industries to examine the impact of environmental activities on the performance of the organization. The industries in the analysis varied from technology, automotive, and chemical to food, media, retail, and tourism. The analysis period lasted for six months and the research methodology aimed toward determining whether organizations with sustainable practices are more likely to withstand the economic downturn. The sample of the study included sustainability-focused organizations that were part of the Dow Jones Index. The analysis was done in two phases: a three-month phase and a six-month phase. The analysis revealed that during the current economic downturn, organizations with practices that are geared toward protecting the environment and improving the social well-being of the stakeholders while adding value to the shareholders have outperformed their industry peers financially. The financial advantage has resulted from reduced operational costs (energy and water usage, etc.) and increased revenues from the development of innovative green products (Kearney, 2009).

\subsection{TBL in the Literature}

Unlike sustainability, there is considerably less empirical research on TBL. The focus of the studies in the relevant literature varied from accounting/finance to organizational behavior. For example, Hidayati (2011) conducted a qualitative study to understand the extent of utilizing the TBL approach in executing CSR programs in the organization. Moreover, Ho and Taylor (2007) conducted another empirical analysis on TBL reporting using a quantitative approach. The purpose of the study was to examine the extent of TBL reporting and to evaluate how economic, social, and environmental issues are reported. Another empirical research on TBL was done by Goel (2010). The objectives of Goel's qualitative study were to 1) study the construct of TBL and its benefits, 2) analyze the link between TBL and sustainable development, and 3) develop a comparison between the TBL indicators and the sustainable reporting indicators. Despite the lack of significant research on TBL, the studies found have all have referred to the economic, social, and environmental aspects simultaneously. 


\section{Conclusions}

This paper presents an overview of the presence of TBL and sustainability in the relevant literature. Surveying the literature showed an inconsistent usage of sustainability where several studies used the term but were in fact referring to one or two of the three known lines (society, environment, and economy). Used interchangeably, TBL and sustainability are related constructs; however, there seems to be an inconsistent use of sustainability. The results from the literature survey as shown in this paper encourage researchers pay particular attention to the usage of the sustainability term in their research. Therefore, if the researcher elects to use sustainability in light of the social, environmental, and economic pillars (or lines), the work should explicitly state that.

\section{References}

A, A. H. (2013). The influence of triple bottom line on strategic positioning: an exploratory case study on differentiation through image (Doctoral dissertation). Retrieved from ProQuest (3556124).

Ambec, S., \& Lanoie, P. (2008). Does it pay to be green? A systematic overview. Academy of Management Perspectives, 22(4), 45-62. http://dx.doi.org/10.5465/AMP.2008.35590353

Aras, G., \& Crowther, D. (2009). The durable organization in a time of financial and economic crisis. Economics and Management, 14, 210-216.

Bibri, M. (2008). Corporate sustainability/CSR communications and value creation: A marketing approach. (Master's thesis). Retrieved from WorldCat Dissertations. (OCLC: 747412678).

Brundtland, G. (1987). Our common future: The world commission on environment and development. Oxford, England: Oxford University Press.

Collins, C., Steg, L., \& Koning, M. (2007). Customers' values, beliefs on sustainable corporate performance, and buying behavior. Psychology and Marketing, 24(6), 555-577. http://dx.doi.org/10.1002/mar.20173

Dewangga, A., Goldsmith, S., \& Pegram, N. (2008). Social responsibility guideline and sustainable development: Integrating a common goal of a sustainable society. (Master's thesis). Retrieved from WorldCat Dissertations. (OCLC: 747412684).

Dhiman, S. (2008). Product, people, and planet: The triple bottom line sustainability imperative. Journal of Global Business Issues, 2(2), 51-57.

Dyllick, T., \& Hockerts, k. (2002). Beyond the business case for corporate sustainability. Business Strategy and the Environment, 11, 130-141. http://dx.doi.org/10.1002/bse.323

Elkington, J. (1997). Cannibals with forks - Triple bottom line of 21st century business. Stoney Creek, CT: New Society Publishers.

Epstein, M. (2008). Making sustainability work: Best practices in managing and measuring corporate social, environmental, and economic impacts. San Francisco: Greenleaf.

Frame, B., \& Newton, B. (2007). Promoting sustainability through social marketing: Examples from New Zealand. International Journal of Consumer Studies, 31, 571-581. http://dx.doi.org/10.1111/j.1470-6431.2007.00600.x

George, H. (2009). Progress and poverty. Cambridge: Cambridge University Press. (Original work published 1879). http://dx.doi.org/10.1017/CBO9780511693687

Goel, P. (2010). Triple bottom line reporting: An analytical approach for corporate sustainability. Journal of Finance, Accounting, and Management, 1(1), 27-42.

Harmon, J., Bucy, F., Nickbarg, S. Rao, G., \& Wirtenber, J. (2009). In Wirtenberg, J., Russell, W., \& Lipsky, D. (Eds.), The Sustainable Enterprise Fieldbook,(89-115). New York: Greenleaf Publishing.

Henriques, A. (2007). CSR, sustainability and the triple bottom line. In Henriques, A., \& Richardon, J. (Eds). The Triple Bottom Line: Does it All Add Up? London: Earthscan. (pp. 26-33).

Hidayati, N. (2011). Pattern of corporate social responsibility programs: A case study. Social Responsibility Journal, 7(1), 104-117. http://dx.doi.org/10.1108/17471111111114576

Ho, L., \& Taylor, M. (2007). An empirical analysis of triple bottom-line reporting and its determinants: Evidence from the United States and Japan. Journal of International Finance Management and Accounting, 18(2), 123-150. http://dx.doi.org/10.1111/j.1467-646X.2007.01010.x

Kearney, A. (2009). "Green" winners: The performance of sustainability-focused organizations during the financial crisis. http://www.sustaincommworld.com/pdfs/ATKearney_Green_Winners.pdf. 
Lippman, E. (2010). Case study on sustainability: Accountants' role in developing a new business model. http://papers.ssrn.com/sol3/papers.cfm?abstract_id=1662648.

Marcus, A., \& Fremeth, A. (2009). Green management matters regardless. The Academy of Management Perspectives, 23(3) 17-26. http://dx.doi.org/10.5465/AMP.2009.43479261

Norman, W., \& MacDonal, C. (2004). Getting to the bottom of the triple bottom line. Business Ethics Quarterly, 2(14), 243-262. http://dx.doi.org/10.5840/beq200414211

Rogers, K., \& Hudson, B. (2011). The triple bottom line: The synergies of transformative perceptions and practices of sustainability. OD Practitioner, 4(43), 3-9.

Santos, M., \& Filho, W. (2005). An analysis of the relationship between sustainable development and the anthropsystem construct. International Journal of Environmental and Sustainable Development, 4(1), 78-87. http://dx.doi.org/10.1504/IJESD.2005.006775

Savitz, A., \& Weber, K. (2006). The triple bottom line: How today's best-run organizations are achieving economic, social and environmental success - and how you can too. San Francisco: Jossey Bass.

Shrivastava, P., \& Hart, S. (1992). Greening organizations. Academy of Management Best Paper Proceedings, 52, 185-189. http://dx.doi.org/10.5465/AMBPP.1992.17515480

Spangenberg, J. (2005). Economic sustainability of the economy: Constructs and indicators. International Journal of Sustainable Development, 8(1/2), 47-64. http://dx.doi.org/10.1504/IJSD.2005.007374

Yan, W., Chen, C., \& Chang, W. (2009). An investigation into sustainable product constructualization using a design knowledge hierarchy and Hopfield network. Computer and Industrial Engineering, 56(4), 617-626. http://dx.doi.org/10.1016/j.cie.2008.10.015

\section{(cc) EY}

This work is licensed under a Creative Commons Attribution 3.0 License. 